\title{
Limits of the National Surveys Predictive Capabilities, or, The Future of America
}

\author{
TAYLOR P. (2014) THE NEXT AMERICA: BOOMERS, MILLENNIALS AND THE LOOMING GENERATIONAL \\ SHOWDOWN, NEW YORK: PUBLIC AFFAIRS, 288 P. ISBN 9781610393508
}

\author{
Irina Trotsuk \\ Associate Professor, Peoples' Friendship University of Russia \\ Address: 10/2 Miklukho-Maklaya str., Moscow, Russian Federation 117198 \\ E-mail: irina.trotsuk@yandex.ru
}

\begin{abstract}
We're fond of the aphorism "Everyone is entitled to his own opinions, but not to his own facts." We think good data make good facts, and we're just idealistic enough to believe that a common foundation of facts can help societies identify problems and discover solutions. (p. vii)
\end{abstract}

If you bring social scientists and journalists into the same sandbox and give them the right tools, values, and missions, you can create a new kind of institution-a "fact tank"-that helps people understand the world around them. (p. 20o)

Whether you like it or not, or agree or strongly oppose such an assertion, we all live, or believe to be living in a world constructed from sociological data, mainly from the results of surveys. The beginning of the present era of national representative surveys is primarily associated with the name of George Horace Gallup, an American pioneer of survey sampling techniques, and the inventor of the Gallup poll. There is a quite wellknown fact that in the 1936 presidential elections in the United States, the Literary Digest magazine conducted a poll based on over two million written questionnaires returned by mail which predicted that Alf Landon would be the winner. George Gallup carried out a survey on a random representative sample of a few thousand Americans, and predicted that Franklin Roosevelt would defeat Alf Landon in the U.S. Presidential election. He also predicted that the forecasts of the Literary Digest would be wrong because the results of the magazine's poll were based on a sample of people who were registered as telephone or car owners, and did not represent all of the voting groups of American society at that time.

Certainly, Gallup was not the only creator of the small representative sample and faceto-face interviews methodology. In fact, "the adequate understanding of George Gallup's

(C) Irina Trotsuk, 2014

(c) Centre for Fundamental Sociology, 2014 
achievements indispensably requires a detailed study of the heritage of other pollsters who explored the political and consumer attitudes of Americans from 1930 to 1950 " as well, such as Archibald Crossley, Hadley Cantril, Elmo Roper, Robert and Helen Lynd, Alfred Charles Kinsey, etc. They created the methodology and the industry of public opinion polls, and "fundamentally changed the concept of the U.S. public about social science in general and its methods too, and, most importantly, transformed the views of people about themselves. Prior to these studies, society was dominated by the perception that social scientists studied exclusively social problems, whereas afterwards people saw themselves for the first time."

However, the names of Gallup, Crossley, and Roper not only stand for the symbolic designation of the beginning of the era of an absolute faith in the predictive power of representative surveys and sampling techniques, but also for the synonym of the deepest collapse of the sociological dream of acquisition of the methodology guaranteeing the way to obtain the true knowledge once and for all. In 1948, when the American society trusted in the technology of sample-based public opinion polls, and the forecasts of Gallup, Crossley and Roper, propagated by the press and radio broadcasts, were attracting enormous attention, this scientific trio had their moment of greatest ignominy, called "the 1948 great fiasco," when they predicted that Republican Thomas Dewey would defeat Democrat Harry Truman. Of course, during the first years of electoral polling, there was a continual criticism of errors in the forecasts about regional and local elections outcomes, sampling arrangements, and wordings of separate questions, but such a resounding failure was completely unexpected.

The trio did not accept that there were any fundamental shortcomings in the measuring instrument they invented, or that such a failure denied the importance and the necessity of studying public opinion. Gallup was sure that the problem was not in the eventually-inappropriate sampling procedure, but in the early discontinuation of polling three weeks before Election Day. This was due to the mistaken belief that nothing much changes in the last few weeks of the political campaign. The subsequent methodological studies of the public opinion polls pioneers aimed at overcoming critical remarks that can be disaggregated into three groups: "addressed, first, towards the wording of the questions and the selection of the words, second, towards the size of the used samples and their structure, and, third, towards the existence of the very possibility to reveal public opinion."' These studies helped the new surveys' methodology pass successfully the toughest tests of the subsequent decades. This success allowed public opinion polls to gradually become an integral part of the political system and everyday social life, not only in the United States, but also in other countries, including Russia.

The reader may quite rightly ask why he has to wade through such a long preface to the review of the book that seems to be quite simple and, indeed, is easy to read, which does not diminish its undeniable merits. The answer is evident: today, at least in Russia,

1. Doktorov B. (2011) George Gallup: biografija i sud'ba [George Gallup: Biography and Destiny], Kaluga: Poligraf-Inform, p. 16.

2. Ibid.: 148 
none other than the sociologists themselves turned out to be the most stringent and tough critics of public opinion surveys. This situation is deeply depressing for two reasons. First, both theoretically- and empirically-oriented sociologists critically assess the state of the public opinion polls industry. The "theorists" question the sociological affiliation of the polls in wondering why everybody thinks that asking $1,200-1,500$ respondents in different places across the country specific questions at a specific time should automatically make one a sociologist even if adequate, reliable and useful data is provided for political and marketing purposes. ${ }^{3}$ The "methodologists" argue about the structure and status of the sociological knowledge, focus on the reliability of the data, and criticize quantitative research practices for being "artifactual" and "a sly game of numbers." 4 The "empiricists" doubt the objectivity, reliability, and scientific independence of the public opinion polls, and refer to the recurring failures of the electoral forecasts, to the strange and exotic (because of its enormous price and unrealistic terms) government tenders seeking information through sociological studies, and to the fact that today any public authority, businessman, or individual possessing enough financial resources is able to make a sample, to construct a questionnaire, to conduct a survey, and to present the entire palette of "necessary" data distributions, that is, happens to be a "sociologist." Secondly, the politicians unexpectedly became the main advocates of public opinion surveys, which allows them to impudently manipulate the data to convince the population of the correctness of the decisions proposed, or already implemented. For example, take the infamous "Crimean survey" and the media buzz around Vladimir Putin's mentioning it as the proof of the unprecedented public support of the Russian Federation's political decision to make the Crimea a part of Russia.

Sociologists accept the challenges mentioned, but, unfortunately, generally prefer to confront methodological, technical and reputational attacks by attempts to solve two basic problems of public opinion polls. These problems are (1) measurement errors "caused" by the "tools" of the survey (questionnaire design, structure and content, interviewers and supervisors work, too formal perception of communicational features, etc.), and (2) representational biases due to the discrepancies between the projected and the actual sampling. As a result, we are drawing in an endless sea of data collected over decades of empirical research, gathered in thousands of archival documents and databases, reflecting all possible aspects of public opinion. However, we are still not interested in the interpretation of the information treasure that the generations of Russian sociologists have obtained, or turn to it for illustrative rather than analytical purposes. It does not really matter how we describe the situation, whether as an epistemological paradox of the exponential growth of the social data and the proportional reduction of its explanatory potential, or as an information explosion causing the situation where sociologists lag behind

3. See, for example, Filippov A. (2014) Sociologija i/ili filosofija dejstvija [Sociology and/or Philosophy of Action]. Available at: http://www.polit.ru/article/2014/11/27/filippov (accessed 7 December 2014).

4. See, for example, Voronkov V. (2004) Etot bezumnyj, bezumnyj, bezumnyj kolichestvennyj mir [What a Crazy, Crazy, Crazy Quantitative World]. Neprikosnovennyj zapas, no 3, pp. 23-26.

5. See, for example, Rogozin D. (2014) Lgut li oprosy obshhestvennogo mnenija v Rossii? [Do the Public Opinion Polls in Russia Lie?]. Available at: http://postnauka.ru/longreads/36509 (accessed 7 December 2014). 
the sociology. The crux of the problem does not change: we ignore both the explanatory and predictive capabilities of the survey data, because we are too focused on achieving the "right" data, rather than analyzing and interpreting the existing set.

Therefore, the book The Next America by Paul Taylor completely falls outside of the general (at least Russian) critical sociological trend. It does not contain a single mention of the survey problems related to the sampling procedures, questionnaire design, or other issues of obtaining valid sociological data through public opinion polls. The book focuses exclusively on the predictive capabilities and limits of forecasts based on the representative national surveys conducted mainly by the Pew Research Center. ${ }^{6}$ The author emphasizes that such predictive capabilities depends not only on the data itself. It also depends on its right contextualization with the results of other research projects, and expert opinions provided by politicians, journalists, and scientists representing different disciplinary fields. To put it more precisely, there are two key themes in the book: first, the current state of the American society "measured" by public opinion polls, and examined primarily through the generational prism, and second, the future of the American society as predicted by national surveys. The data on both topics is contextualized by a wide variety of non-sociological and non-through-surveys-gathered information. Furthermore, an interested Russian reader can discover a third tacitly-assumed theme in the text, being the collapse of his favorite stereotypes about American society (provided that he had such).

Let us begin with the first thematic line of the book. It should be noted that the two thematic lines are identified by the reviewer and closely intertwined in the author's narrative. Actually, the book consists of twelve chapters typical for such editions: on generations ${ }^{7}$, generational gaps, financial problems, digital competence disparities between

6. Pew Research Center opened a decade ago, and Paul Taylor has served as its executive vice president overseeing the Social \& Demographic Trends project, the Hispanic Trends project, and various center-wide research initiatives. Before that, he was a newspaper reporter for twenty-five years, the last fourteen at the Washington Post, where he covered three U.S. presidential campaigns. The Pew Research Center staff consists of public opinion survey researchers, political scientists, demographers, economists, sociologists, and ex-reporters

7. There are following generations in the contemporary American society: the Greatest Generation refers to those born before 1928; the Silent Generation, those born from 1928 to 1945 (the Silents are the oldest, most financially secure and most unsettled by the ongoing social changes, conservative and conformist, uneasy with the pace of demographic, cultural, and technological change); the Baby Boom Generation, those born from 1946 to 1964 (the Boomers will be crashing through the gates of old age in record numbers for the next two decades, not nearly as well financially fortified for the journey as they had hoped, giving reasons why they are gloomy about their lives, worried about retirement, and wondering why they are not young any more); Generation X, those born from 1965 to 1980 (the Xers are navigating middle age with mounting economic anxieties about their old age, are savvy, entrepreneurial loners, distrustful of social institutions); the Millennial Generation, those adults born after 1980, the youngest members of the generation still being in their teens (the Millennials are twenty-somethings and a lot of them landed back in their childhood homes in record numbers pushed out by the hostile economy; they are empowered by digital technology, coddled by parents, respectful of elders, slow to reach adulthood, conflict-averse, and at ease with racial, ethnic, and sexual diversity); there is still no chronological point for their successor generation. Boomers ( 76 millions) and Millennials (8o millions) are the biggest of the four living generations, each significantly larger than the generation that came before (Silents and Xers, respectively). 
different age groups, the aging problems, etc. The preface lays the beginning for the first thematic line of the book when the author states that the America of his childhood "with its expanding middle class, secure jobs, intact nuclear families, devout believers, distinct gender roles, polite politics, consensus-building media" is nothing like the country his year-old granddaughter will inherit. He writes that nowadays, "political, social, and religious institutions are weaker, middle class smaller, cultural norms looser, public debate coarser, technologies faster, immigrant-woven tapestry richer, racial, ethnic, religious, and gender identities more ambiguous, the society more polarized and more tolerant" (p. vii).

Hereinafter, referring (a) to the great number of tabulated and charted data gathered by different researchers; (b) to the opinions of scholars, academics, and journalists, whose names appear throughout the book in citations, quotes, and footnotes; (c) to the interview of Natalie Marks (a pseudonym), the young woman whose digital coming-ofage story gave some chapters a narrative arc; (d) to the well-known facts (for example, that longer life spans and improving living standards beget lower birthrates); and (e) to the quite unexpected conclusions (for example, that Japan has become the global leader in the development and manufacture of caretaker robots since, and that by 2050, there will not be nearly enough young caregivers for the aged in the country), the author consistently examines in what way each of the basic elements of the contemporary American society has already transformed, and in what direction some important changes are still unfolding.

The first main idea of the book is that there changes no one pays attention to (though should) until he (or society as a whole) takes a hard look around at itself and notices that things are different. The most striking example of rare and revealing "aha" moments are demographic transformations, because they are "dramas in slow motion, unfold incrementally, almost imperceptibly, tick by tock, without trumpets of press conferences" (p. 1). Such an "aha" moment occurred in America on November 6, 2012, the night of President Barack Obama's reelection victory. His victory revealed the meaning of the demography for the politics, and convinced politicians that the United States turned to be a country with a permanently high-turnout of blacks, Latinos ${ }^{8}$, and young people. If it were otherwise (a country of a high turnout of whites, men, and older people), Mitt Romney would have won by millions of votes. Thus, if any political party wishes to be competitive in future presidential elections, it needs to become more appealing to the nation's newly most racially and ethnically diverse electorate. The second main idea of the book is that we need a generational frame to illuminate the demographic, economic, social, cultural, and technological changes in the remaking of not only national politics, but also of families, livelihoods, relationships, and identities, that is, the everyday life of Americans. These shifts have left no realm of American society untouched.

What are the key reasons that made American society more unequal, more diverse, more mixed-race, more digitally-linked, more tolerant, less-married, less fertile, less re-

8. The terms "Latino" and "Hispanic" are used in the book interchangeably, because Hispanics can be of any race. 
ligious, less mobile, and less confident, its political and social institutions and the public itself more polarized and partisan, and its economy producing more low- and high-wage jobs with fewer opportunities in between? As a result, the middle class is shrinking, median household income has flatlined, the wealth gaps between the rich and the poor, the young and the old, the whites and the blacks have widened to the levels never before seen in modern times. ${ }^{9}$ Let us start with the gender "dimension" of the ongoing changes. It is not limited to the fact that "the sex-without attachment rules apply equally to young men and women and leave both genders emotionally shortchanged" (p. 20). Women have become more economically independent, and gender roles are converging both at work and at home, which contributes to the further decline of marriage. The fastest-growing household type in America contains just one person (nearly 3 in 10 households today contain just one person, double the share in 1960). ${ }^{10}$ An American teenager has less chance of being raised by both biological parents than anywhere else in the world. Women have become the sole or primary breadwinners in 4 in 10 households with children (a half century ago, it was 1 in 40); a majority of these "breadwinner moms" are unmarried, and $37 \%$ of wives earn more than their husbands. According to a Pew Research poll in 2011, $66 \%$ of young women ( $59 \%$ of young men) were sure that being successful in a highpaying career or profession was a very important life priority. In the same year, the share of the male labor force declined to $53 \%$ (it was $62 \%$ in 1970), and that of women increased to $47 \%$ (from $38 \%$ in 1970). This reversal of traditional gender expectations has become possible also because the public overwhelmingly supports the trend toward more women in the workforce, and more egalitarian marriages, where both spouses are trying to balance work and family. Nonetheless, many traditional gender norms still endure, at least declaratively. For example, in 2013, about half of respondents believed that children were better off if the mother stayed at home, with just $8 \%$ saying the same if the father stayed at home.

According to Pew Research data, existing economic and financial hardships ("the wretched economy") bring families together. The second fastest-growing household type in America are multigenerational households, in which two or more adult generations live together, often because that is the only way to make ends meet. Forty per cent of all Millennial men ages 18 to 31 , and $32 \%$ of young women of that age, were living in their parents' homes in 2012. This is the highest share in modern history that symbolizes either post-adolescence or pre-adulthood (delayed adulthood) (p. 19). This fact, by the way, contradicts the Russian stereotype that American society is made of only nuclear families consisting of parents and minor children. Even when multiple generations do not live in the same home, they look after one another in other ways. Adults provide various forms of caregiving to elderly parents, well-to-do seniors provide financial assistance to

9. The book is so full of data that it is not possible to summarize all the trends thoroughly described in it. 10. For more details see, for example, Klinenberg E. (2013) Going Solo: The Extraordinary Rise and Surprising Appeal of Living Alone, London: Penguin Books. However, such "post-familialism" or "new singleism" is a global phenomenon, having taken root not just in the U.S., but in Canada and the wealthy countries of Europe and East Asia due to the urbanization, secularism, women's economic empowerment, and higher standards of living. 
adult children buying homes or to grandchildren going to college, grandparents contribute their time in caring for their grandchildren, and the biggest intergenerational family transfer is inheritance.

Secondly, a perceived Russian stereotype is that the basis of the American society is a strong and huge middle class. However, the American middle class has suffered its worst economic run since the Great Depression. It has decreased in size, has fallen backward in income and wealth, and has shed some of its characteristic faith in the future. Approximately $85 \%$ of Americans believe it has become tougher to live a middle-class lifestyle than it was a decade ago. Nevertheless, most middle-class Americans believe that they have a better standard of living than their parents at the same age, that their children will do even better than they did. This demonstrates the trademark optimism of the American middle class, albeit not as well-founded as it used to be. The third Russian stereotype is that the U.S. is a land of great and equal opportunities, "but today a child born into poverty in Canada and most Western European countries has a statistically better chance of making it to the top these days than does a poor kid in the U.S." (p. 9).

Today, "young adults are taking longer to grow up; the middle-aged longer to grow old; and the elderly longer to depart this vale of tears" (p. 4). Taylor writes that "The Millennials' (twenty-somethings') two seemingly incompatible characteristics-their slow walk to adulthood and their unshaken confidence in the future (they are America's most stubborn optimists and humankind's first generation of digital natives believing that the whole world wants to see your funny cat photos) - are their most distinctive traits" (p. 20). Pessimists believe that the reason for the slow walk to adulthood is the unemployment crisis, which is partly true, because as Millennials are entering the workforce, Boomers are entering retirement. However, hard times and bad choices lead to the juxtaposition that some of the jobs Boomers are not leaving are the same jobs Millennials are not getting. Boomers seem to have experienced less happiness on average than have other generations over the entire life spans. There are two reasons for this; first, the very size of their cohort has led to a lifetime of stressful intragenerational competition for a limited share of top spots in schools, colleges, and careers, and secondly, they are having trouble getting their minds around the idea that they are not young anymore. As a result, Millennials are the most "dependent" generation for "their futures will be enhanced or encumbered by choices their elders are making now" (p. 28).

The author asserts the existence of an unusually large generation gap in American society today. He admits that generation gaps are hardly a novelty, and refers to the words of Alexis de Tocqueville, that in America, "each generation is a new people" (p. 30), but today demographically, politically, economically, socially, and technologically, generations are more different from each other ${ }^{11}$ (especially the young from the old) than at any time in living memory. They have a different racial and ethnic makeup (nearly half of all chil-

11. Taylor is very careful within the generational analysis frame: he acknowledges that there are as many different personality types within a generation as across generations, but generational generalizations do have some value, because people bear the marks of their distinctive coming-of-age experiences providing them unique generational identities. 
dren today are nonwhite); they vote differently; their economic fortunes have diverged (the typical household headed by someone aged 65 or older has 26 times the net worth of the typical household headed by someone under the age of 35); their families are different (the shares of unmarried twenty-somethings and unmarried mothers have increased); their gender roles are converging (the share of women among the family breadwinners, college students, and the labor force has grown significantly); they have different ideas about the role of government (older citizens prefer a smaller government that provides fewer services, while younger citizens prefer a bigger government with more services), of religion (Millennials are the least religiously connected generation in modern American history), about American exceptionalism (a majority of older Americans believe that the U.S. is the greatest country in the world); they have a different take on the digital revolution (especially the Internet), and different appetites for news (Millennials are consuming less news than older generations did when they were younger).

The U.S. public opinion, in the aggregate, has changed dramatically in two ways. On the one hand, biases against minorities and gays are diminishing, especially among younger generations. For example, a half of adults support same-sex marriage, with a considerable generation gap with about $70 \%$ of young Americans and 30\% of older citizens supporting its legalization. On the other hand, there is a growing tendency of people to sort themselves into political parties based on their ideological differences. Liberal Republicans and conservative Democrats have always had different opinions, but the problem is that these days they also seem to have different facts. Perception gaps have increased, because politicians spend too much time "in today's version of Plato's cave, trading their "facts" back and forth in a media-saturated echo chamber of think-alike colleagues, readers, tweeters, and viewers" (p. 15).

Taylor also writes that "Immigration is the engine that makes and remakes America ... and today the engine is roaring again to reengineer the compact between the generations. . . Immigrants are strivers. They have energy, ingenuity, a tolerance for risk, an appetite for hard work, and a faith in the future. Few if any countries have been more enriched by immigrants. And not many countries are better at weaving them into the social, political, and economic fabric of their new home. ... Even so, Americans don't typically welcome newcomers with arms fully extended, especially not when they arrive in large numbers" (p. 69). Today's America is home to a record 42 million immigrants ${ }^{12}$ and 37 million US-born children of immigrants. Today's immigrants (9 of 10 are not Europeans) look very different from the previous waves of settlers and immigrants who created America. However, it is difficult to find more fervent devotees of the traditional American values (we are not talking about being more law-abiding than other Americans, because immigrants know any brush with the law could result in deportation). Hispanics and Asians, on the one hand, embrace values common to immigrant groups (hardworking, family-oriented, entrepreneurial, and freedom loving) that could easily make them natural Republicans but did not. They favor an active government, and tend to be social

12. The terms "first generation," "foreign born" and "immigrant" are used in the book interchangeably. 
liberals. Moreover, "the deeper Hispanics and Asian Americans and their adult children have sunk their roots into America, the more Democratic they have become" (p. 84). The immigrants are also the face of the country to the world, since "their life stories embody the values the nation holds most dear: pluralism, dynamism, tolerance, entrepreneurship, achievement, optimism" (p. 87).

Nevertheless, the problem is that older generations are predominantly white, and younger generations increasingly nonwhite, which results in "different political philosophies, social views, and policy preferences" (p. 5). The young are big government liberals, the least religiously-connected in modern American history, comfortable with the new lifestyles, family forms, and technologies that disorient most of the old. The young start their working and taxpaying lives in the worst economy since the Great Depression. The old are small-government conservatives, the most devout believers in the industrialized world. They are finishing their retirement years costing trillions of dollars to the governmental Social Security and Medicare systems that their children and grandchildren will spend their lives paying off.

The modern immigration wave has not only boosted the American economy, but has given the country a racial makeover, made it multicolored, and changed old racial labels that are having trouble keeping up with the new marriage trends. In more than a quarter of all recent Hispanic and Asian marriages, 1 in 6 black, and 1 in 11 white newlyweds are married to someone of a different race or ethnicity; "not too long ago these marriages were illegal and taboo, now they barely raise an eyebrow" (p. 7). Thus, race is becoming more subtle and shaded, and forces society to find a modern vocabulary for accurate racial identification markers, since the existing labels, categories, and classification schemes have not kept up with the ongoing wedding, birth, and identification choices. For example, responses to the question of what Barack Obama is racially depends on the wording, the context, and whom you ask; most blacks call him black, while most whites say he is of mixed race.

The author concludes that the American twentieth-century metaphor of the "melting pot" has turned into the metaphor of a "mosaic" in a more racially and ethnically diverse nation to reflect the differences in the assimilation processes. Today, "every piece contributes to a whole, but not by losing its distinctiveness" (p. 74). However, America has not become "a postracial society," although "there are fewer out-and-out bigots and the new racial landscape is increasingly bursting with nuance, shadings, subtleties, possibilities, ironies" (p. 96). There are still significant gaps between blacks and whites in household income and wealth, high school completion, life expectancy, and unemployment rate. Black men are six times as likely as white men to be incarcerated. Most of the racial gaps between blacks and whites in key personal finance indicators widened during the 2007-2009 recession and have since remained at these elevated levels. However, reality is one thing, perception another; "most blacks joined with most whites in saying that the two racial groups have grown more alike in the past decade, both in their standards of living and their core values" (p. 105). 
Race is not the only changing demographic characteristic. Another is religion. It is not just that the American public is becoming less white and less Protestant. American society is also becoming less attached to religious denomination in general. Nowadays, 1 in 5 American adults and a third under the age of 30 is religiously unaffiliated; three quarters of the so-called "nones" believe in God, but have no religious affiliation. Approximately three-quarters of now-unaffiliated adults were raised with an affiliation (74\%). The author, referring to the Pew Research surveys, lays to rest some common misperceptions about the "nones," and shows that (1) disaffiliation has taken place across different demographic groups, regardless of sex, education, income, or place of residence, although the recent change has been concentrated in one racial group, that is of white Americans; (2) the unaffiliated are not uniformly secular, sonce most of them believe in God; (3) nor are the "nones" uniformly hostile toward organized religion, although they are much more likely than the public overall to say that churches and other religious organizations are too concerned with money, power, rules, and politics. Nevertheless, despite the disaffiliation trends, the U.S. remains a highly religious country and is still the most religiously observant nation among the world's great powers. However, American youngsters lead the society in being more pluralistic and less connected to traditional religious institutions.

The second thematic line of the book is inspired by the belief of the author expressed in the preface that "Change is the constant. No matter what we're like today, we're going to be different tomorrow" (p. vii). The author does not criticize or endorse the changes, because "some are for the better, some for the worse, and some people no doubt will differ over which is which, but most are mutually reinforcing" (p. 4). He rather seeks to predict the results of the ongoing changes, for while it is interesting and inevitable to live in a constantly changing world, we feel depressed and confused if we do not understand the general direction and possible consequences of changes for ourselves, and society as a whole. According to the U.S. Census Bureau, nonwhites will become the majority of the population in 2043 . The share of whites has declined from $85 \%$ in 1960 to $64 \%$ in 2010 , and projected to become $43 \%$ in 2060 . However, their place will not be taken by blacks or Chinese, as most Russians would think, referring to Hollywood blockbusters or common national stereotypes about America. The share of blacks and Asians ${ }^{13}$ is projected to change slightly (from $12 \%$ in 2010 to $13 \%$ in 2060 for blacks, and from $5 \%$ to $8 \%$ for Asians), while the share of Hispanics will increase from $16 \%$ to $31 \%$. By 2050 , an estimated 162 million Americans (37\% of the population) will be "immigrant stock" (immigrants themselves or their US-born children). This would be the highest percentage in the U.S. history. We witness that men and women "navigate a brave new world of gender convergence," which supports the decline of traditional marriage, but it is not clear yet how well the institution of marriage will survive, and in precisely what forms; "No one knows what the future holds, but it's clear that the ever-changing digital landscape is likely to keep generation gaps quite wide for the foreseeable future and may even change the very nature of what it means to be human and to grow old" (p. 156).

13. Asians also include Native Hawaiians and Pacific Islanders. 
The author believes that his work should not be taken as "a gloom-and-doom book," though it portrays the American society as tugged at by centrifugal forces, and its two basic institutions, the government and the family, shaken to their cores. In addition, the book describes the preconditions for "a generation war," "the unsparing arithmetic of a graying population is about to force political leaders to rewrite the social contract between young and old. This will lead to tax increases, benefit cuts, or both. Taking stuff away from people is never popular in a democracy, but it's particularly fraught on this issue at this time, because old and young in America are so different-racially, ethnically, politically" (p. 45). Nevertheless, the author believes the book provides too many "findings that give voice to the optimism, pragmatism, and resilience of the American public, even in the teeth of dysfunctional politics, rising inequality, frayed families, and anemic labor markets" (p. 15). There is much evidence to be optimistic. The generations are interdependent in their family lives; the young are every bit as supportive as the old and have a great respect for their elders, and "seem much more disposed toward cooperation than conflict, perhaps because of the nurturing parental norms that guided their upbringing" (p. 46). Thus, "America isn't breaking apart at the seams. The American dream isn't dying. ... The nation faces huge challenges, no doubt. So do the rest of the world's aging superpowers. If you had to pick a nation with the right staff to ride out of the coming demographic storm, you'd be crazy not to choose America" (p. 15). As a result, one must admit that this is a very optimistic (but not blinkered optimism), life-affirming, and convincing statement, thoroughly well-founded in the book by the survey data and thoughtful generalizations (even though just small parts of both are presented in the review, and in a quite incomplete way).

The book is remarkably concise and surprisingly informative, with the preface possesses both features. For this reason, the general conclusion of the book is already given, with the following text aiming to confirm it. In exploring the many ways America is transforming, the author raises the question of the generational responsibility within the ongoing, unprecedented changes that produce longer life spans and the difficulties of getting old, lower birth rates, and the difficulties of finding the road map to adulthood, because "the generations relate to one another not only as citizens, voters and interest groups, but as parents, children, and caregivers in an era when the family itself is one of the institutions most buffeted by change" (p. vii-viii). The new demographics of aging means that the future American society will not be able to pay those costs and thus unable to fulfill the promises made to the older generations without bankrupting the young and starving the future. This situation may set off a generation war, although this is not a foregone conclusion, for "the drama doesn't have to end in tragedy if the generations bring to the public square the same genius for interdependence they bring to their family lives" (p. 5).

The author confesses, that as a political reporter years ago, he used to have a weakness for trying to forecast election outcomes, but now does not presume to know how the story he tells will end. He ventures to describe only the current state of affairs and a future which anyone can figure out if demographics and public opinion polls data are carefully 
studied. The author wants to be just "a tour guide who explains how the nation got from the middle of the last century to the present and to provide some insights about what this breathtaking journey tells us about changes yet to come" (p. viii). I must admit the author is an excellent guide and succeeded amazingly well with the task he has set himself to. What a pity that, so far, none of the Russian sociologists have dared to play the same role. However, let us hope that is still ahead.

\section{Пределы прогностических возможностей общенациональных опросов общественного мнения, или Возможное будущее Америки}

\section{Ирина Трочук}

Кандидат социологических наук, доцент кафедры социологии факультета гуманитарных и социальных наук Российского университета дружбы народов

Адрес: ул. Миклухо-Маклая, д. 6, Москва, Российская Федерация 117198

E-mail: irina.trotsuk@yandex.ru

Рецензия: Taylor P. (2014) The Next America: Boomers, Millennials and the Looming Generational Showdown (New York: Public Affairs) 